\title{
Diabetes in Borgou Department in Benin: Prevalence and Associated Factors*
}

\author{
François Djrolo"\#, Thierry Adoukonou², Corine Houehanou³, Josel D. Houinato², \\ Dismand Houinato ${ }^{3}$ \\ ${ }^{1}$ Department of Internal Medicine, Faculty of Health Sciences, Endocrinology and Metabolic Diseases Unit, \\ Cotonou, Bénin \\ ${ }^{2}$ Faculty of Medicine, University of Parakou, Parakou, Bénin \\ ${ }^{3}$ National Program against Non-Communicable Diseases, Ministry of Health, Cotonou, Bénin \\ Email: "
}

Received 26 February 2015; accepted 3 May 2015; published 6 May 2015

Copyright (C) 2015 by authors and Scientific Research Publishing Inc.

This work is licensed under the Creative Commons Attribution International License (CC BY).

http://creativecommons.org/licenses/by/4.0/

(c) (7) Open Access

\section{Abstract}

An epidemic trend is observed in the evolution the epidemiology of diabetes mellitus worldwide. In a nationwide survey conducted in 2008 , prevalence of diabetes was estimated to $2.6 \%$ in the hole Beninese population and to $4.6 \%$ in Borgou department representing the highest in the country. Aim: To determine the prevalence of diabetes mellitus in the adult population and investigate associated factors in Borgou department. Method: A survey was conducted from September $3^{\text {th }}$ to November $20^{\text {th }}$ 2011. In a random sampling using the STEP wise approach of surveillance of chronic diseases recommended by the World Health Organization, 4597 subjects over 18 years old (1935 men and 2662 women) were selected. After informed consent, every subject was submitted to the STEP questionnaire and anthropometric measures. Capillary blood was drawn in fast condition to determine glycaemia. Diabetes was defined by fasting glycaemia above $1.26 \mathrm{~g} / \mathrm{l}$. Chi square test was used for statistical analysis and difference was considered significant with $p<0.05$. Results: Prevalence of diabetes was $\mathbf{1 2 . 4 \%}$. There was not a significant difference between men $(8.5 \%)$ and women $(9.4 \%), p=0.33$. Prevalence of previously known diabetes was $1.2 \%$ suggesting a large proportion of undiagnosed diabetes. Prevalence of diabetes increased significantly with age $(p<0.0001)$. There was no association with instruction level $(p=0.21)$. Other factors significantly associated with diabetes were place of residency $(p<0.0001)$, ethnicity $(p=0.002)$, marital status ( $p<0.0001)$, obesity $(p=0.017)$ and high blood pressure $(p<0.0004)$. Conclusion: There is a rapid increase in diabetes prevalence in Borgou department in Benin confirming the epidemic trend of the disease. A large proportion of these diabetic subjects remained undiagnosed, so untreated and then, exposed to precocious chronic complications and precocious mortality. These results strongly support need for active intervention program with objectives of primary,

\footnotetext{
*All authors contributed to the realization of the manuscript. An abstract of this work was presented at the world diabetes congress

\#Corresponding author.
} 
secondary and tertiary prevention of diabetes mellitus and associated factors.

Keywords

Diabetes, Impaired Fasting Glycaemia, Prevalence, Associated Factors

\section{Background}

With its epidemic trend reported by several authors [1] [2], diabetes mellitus become a worldwide health concern. The progression of the disease is particularly worrying in developing countries.

When estimates reported by Wild et al. mentioned that the number of people with diabetes will have an increase of $161 \%$ from 2000 to 2030 in sub-Saharan Africa, the increase for the same period will be of 54\% in developed countries [3]. Our country, the Republic of Benin did not make exception to this epidemic trend of the disease. The first nationwide survey carried out in 2001 revealed a prevalence of 1.1\% [4]. In 2008 this prevalence has more than doubled, growing to 2.6\% [5]. At these two occasions, Borgou department shown the highest prevalence rate. Because of its long term complications, diabetes mellitus is responsible of elevated morbidity and mortality [6]. To reduce the negative impact of the disease on the economic development of countries, health actions must be developed to prevent this condition and related complications. Planning these actions must give priority to the more affected areas and need to actualize the range of the disease. The aim of the present study was to determine the prevalence of diabetes mellitus and fasting hyperglycaemia in the Borgou department in Benin in 2011 and to investigate associated factors.

\section{Population and Method}

The study population was constituted by the subjects living in the Borgou department in Benin and who were 18 years or more old. Informed subjects who have given their own consent were included in this study. Were not included, subjects who did not give their consent to participate to the survey, subjects unable to answer questions, pregnant women and subjects presenting any evolutive pathology.

Benin is a French speaking country of West Africa located between Federal Republic of Nigeria at the east, Republic of Togo at the west, Republics of Niger and Burkina Faso at the north and Atlantic Ocean at the south. The administrative organization consists of departments, towns, districts and areas or villages. The Borgou department is located at the north-west part of the country. The estimate population of this department was 969,897 inhabitants.

Sample size was calculated using Schwartz formula with the prevalence rate of $4.6 \%$ corresponding to the prevalence rate observed in 2008, with the absolute precision of 5\%. Hypertension was investigated simultaneously with diabetes. With these conditions, the calculated size was 4636 subjects.

Sampling method: The survey was carried out using the STEP wise approach for the surveillance of risk factors of chronic disease [7] recommended by the World Health organization (WHO). The survey population was selected using grapes sounding technic. Borgou department is divided into 43 districts. Every district represented a grape.

The first step consisted in selecting by random, the half of the districts of the department and then, in itch districts the half of the villages or areas was randomly selected. In the village or area, the half of the household was selected by random.

In every district randomly selected, the half of the areas or villages were selected with random. In the selected area or village, a direction was randomly chosen by the investigator and in this direction, one household out of two was investigated. In the household, the half of menages living in the household was randomly selected and all eligible subjects in this ménage were investigated.

The research protocol was approved by the ethic comity of the ministry of health.

Data were collected from September $30^{\text {th }}$ to November the $20^{\text {th }} 2011$ using the STEP instrument of WHO [7]. The survey team was trained and certified in the use of this instrument. After informed consent, subjects were submitted to the STEP questionnaire in which age and sex were precised. Height and weight were measured and body mass index (BMI) was calculated dividing weight $(\mathrm{kg})$ by the square of height $(\mathrm{m})$. Subjects were consi- 
dered obese with BMI greater than or equal to $30 \mathrm{~kg} / \mathrm{m}^{2}$. Blood pressure was measured on the right arm of seated subject after at least five minutes rest with an OMRON electronic sphygmomanometer on three occasions at fifteen minutes interval. Hypertension was defined by blood pressure higher than or equal to $140 \mathrm{~mm} / \mathrm{Hg}$ for systolic blood pressure and higher than or equal to $90 \mathrm{~mm} / \mathrm{Hg}$ for diastolic blood pressure. After interview and anthropometric measure, selected subjects were sensibilised and the day after, blood was drawn for biochemical measures. In fasting condition since the previous evening meal, capillary whole blood was obtained from a finger puncture and was immediately analysed using a glucometer One Touch Ultra to determine glycaemia. Subjects were considered diabetic if they were previously diagnosed as diabetic or when fasting glycaemia was greater than or equal to $126 \mathrm{mg} / \mathrm{dl}$. Impaired fasting glycaemia was defined with fasting glycaemia between 110 and $126 \mathrm{mg} / \mathrm{dl}$ and glycaemia was considered normal if less than $110 \mathrm{mg} / \mathrm{dl}$ [8].

\section{Statistical Analysis}

For statistical analysis, the Chi-square test was used to compare proportions and student t-test was used for the comparison of means. Differences observed were considered significant with $\mathrm{p}<0.05$.

\section{Results}

A total of 4597 subjects was included in the survey comprising 1935 men (42.1\%) and 2662 women (57.9\%). Mean age of subjects was $37.2 \pm 16.5$ years.

Prevalence of diabetes and impaired fasting glycaemia

Hyperglycaemia corresponding to diabetes mellitus was detected in 414 subjects giving a prevalence rate of $9.0 \%$. In these subjects presenting diabetes only 53 were previously known diabetic. The proportion of undiagnosed diabetes in Borgou department was then $87.1 \%$. The prevalence of impaired fasting glycemia was $12.4 \%$ (569 out of 4597 subjects).

As it appears in Table 1, prevalence of diabetes grows significantly with subjects' age.

The prevalence observed in the different districts investigated is reported in Table 2 . It ranges from $0.6 \%$ to

Table 1. Influence of age.

\begin{tabular}{ccccc}
\hline \multirow{2}{*}{ Age (years) } & Tested Subjects & \multicolumn{2}{c}{ Prevalence of Diabetes } & p \\
\hline$<25$ & 1207 & 77 & 6.4 & \\
$25-34$ & 1232 & 90 & 7.3 & $<0.0001$ \\
$35-44$ & 834 & 69 & 8.3 & \\
$45-54$ & 525 & 63 & 12.0 & 12.8 \\
$55-64$ & 384 & 49 & 15.9 & \\
$\geq 65$ & 415 & 66 & & \\
\hline
\end{tabular}

Table 2. Prevalence of diabetes in the different districts selected.

\begin{tabular}{|c|c|c|c|c|}
\hline \multirow{2}{*}{ District } & \multirow{2}{*}{ Tested Subjects } & \multicolumn{2}{|c|}{ Prevalence of Diabetes } & \multirow{2}{*}{$\mathrm{p}$} \\
\hline & & Number & $\%$ & \\
\hline Bembèrèké & 790 & 17 & 2.2 & \multirow{8}{*}{$<0.0001$} \\
\hline Kalale & 469 & 33 & 7.0 & \\
\hline N'dali & 441 & 48 & 10.9 & \\
\hline Nikki & 365 & 56 & 15.3 & \\
\hline Parakou & 1140 & 90 & 7.9 & \\
\hline Pèrèrè & 162 & 1 & 0.6 & \\
\hline Sinendé & 369 & 56 & 15.2 & \\
\hline Tchaourou & 861 & 113 & 13.1 & \\
\hline
\end{tabular}


15.3\% and the districts of Nikki, Sinende and Tchaourou show the highest prevalence rates.

Six ethnic groups were represented in this survey. The prevalence of diabetes in the different ethnic groups is shown in Table 3.

The highest prevalence rate of diabetes was observed in the Bariba ethnic group.

The association of the prevalence of diabetes with different factors is presented in Table 4 with:

Gender: Men and women

Matrimonial situation regroups: married, widowed, divorced or separated, unmarried

School instruction regroups: none, alphabetized, primary school, secondary school 1 and 2, and university

Tobacco consumption (yes or no); Obesity (yes or no); High blood pressure (yes or no)

Table 3. Prevalence of diabetes in ethnic groups.

\begin{tabular}{|c|c|c|c|c|}
\hline \multirow{2}{*}{ Ethnic group } & \multirow{2}{*}{ Tested Subjects } & \multicolumn{2}{|c|}{ Prevalence of Diabetes } & \multirow{2}{*}{$\mathrm{p}$} \\
\hline & & Number & $\%$ & \\
\hline Bariba & 2867 & 304 & 10.6 & \\
\hline Dendi/Djerma & 188 & 11 & 5.9 & \\
\hline Fonandassimilated & 247 & 14 & 5.6 & \\
\hline Otammari & 265 & 17 & 6.4 & 0.002 \\
\hline Peulh/Gando & 737 & 45 & 6.1 & \\
\hline Yoruba/Nagot & 246 & 19 & 7.7 & \\
\hline Others & 46 & 4 & 8.7 & \\
\hline
\end{tabular}

Table 4. Other factors.

\begin{tabular}{|c|c|c|c|c|c|}
\hline \multirow{2}{*}{\multicolumn{2}{|c|}{ Factors }} & \multirow{2}{*}{ Tested Subjects } & \multicolumn{2}{|c|}{ Prevalence of diabetes } & \multirow{2}{*}{$\mathrm{p}$} \\
\hline & & & Number & $\%$ & \\
\hline \multirow{2}{*}{ Gender } & Men & 1935 & 165 & 8.5 & \multirow{2}{*}{0.33} \\
\hline & Women & 2662 & 249 & 9.4 & \\
\hline \multirow{3}{*}{$\begin{array}{c}\text { Matrimonial } \\
\text { Situation }\end{array}$} & Married & 3419 & 350 & 10.2 & \multirow{3}{*}{$<0.0001$} \\
\hline & $\begin{array}{c}\text { Widowed } \\
\text { Divorced/separated }\end{array}$ & 303 & 42 & 13.9 & \\
\hline & Unmarried & 875 & 5151 & 5.8 & \\
\hline \multirow{6}{*}{$\begin{array}{c}\text { School } \\
\text { Instruction }\end{array}$} & None & 2862 & 271 & 9.5 & \multirow{6}{*}{0.2124} \\
\hline & Alphabetised & 276 & 18 & 6.5 & \\
\hline & Primary school & 487 & 44 & 9.0 & \\
\hline & Secondary school 1 & 520 & 49 & 9.4 & \\
\hline & Secondary school 2 & 325 & 27 & 8.3 & \\
\hline & University & 127 & 5 & 3.9 & \\
\hline \multirow{4}{*}{$\begin{array}{c}\text { Tobacco } \\
\text { Consomption }\end{array}$} & Never & 3703 & 323 & 8.7 & \multirow{4}{*}{0.4315} \\
\hline & Daily & 687 & 67 & 9.8 & \\
\hline & Occasionaly & 129 & 14 & 10.9 & \\
\hline & Past & 78 & 10 & 12.8 & \\
\hline \multirow{2}{*}{ Obesity } & Yes & 259 & 34 & 13.3 & \multirow{2}{*}{0.0171} \\
\hline & No & 4338 & 380 & 8.8 & \\
\hline \multirow{2}{*}{$\begin{array}{l}\text { High blood } \\
\text { Pressure }\end{array}$} & Yes & 768 & 95 & 12.4 & \multirow{2}{*}{0.0004} \\
\hline & No & 3829 & 319 & 8.3 & \\
\hline
\end{tabular}


There was no association with gender or with tobacco consumption. According to the level of instruction, investigated subjects were classified as having none instruction, primary school level, secondary level or university level. In the Borgou department the prevalence of diabetes was not associated with instruction level of subjects but a very significant association was found with matrimonial status.

\section{Discussion}

This study was carried out to determine the prevalence of diabetes mellitus and associated factors. The limitation of the study was the use of one single fasting capillary glycaemia to define diabetes mellitus. Detected subjects would have been confirmed by determining plasma glucose level with a reference test. In our conditions it was very difficult to perform a confirming test in this scale study. Despite this limitation, data collection and statistical analysis were performed with respect of the rigorous conditions recommended by the World Health Organization (WHO) for the surveillance of non communicable disease [7]. Study population size recommended by WHO was 2000 but we have included a total of 4597 subjects in this study. Thus, giving a large scale estimate of the prevalence of diabetes in the Borgou department in 2011, this study provides the baseline data which can help to plane health activities in the field of the prevention of diabetes and associated factors.

The present study revealed a prevalence of diabetes and impaired fasting glycaemia of respectively $9.0 \%$ and 12.4\%. In a similar nationwide survey carried out in Benin in 2001 [6] and 2008, prevalence of diabetes in Borgou department was respectively $4.6 \%$ and $4.6 \%$. This evolution confirmed one more the epidemic trend of the disease announced by the WHO in the world and particularly in developing countries [1] [2] [9]. Regarding the health cost induced by diabetes and its complications, and this rapid rate of progression in Borgou department, this results indicate that in the Borgou department, it is time to act to prevent this disease, following WHO recommendations. This high prevalence of diabetes observed in the Borgou department is in the trend observed in some others regions in African countries: 6.1\% in the Futa Jallon region in Guinea in 2007 [9], 7.2\% in Tunisia [10], 14.2\% in the Tlemcem area in Algeria [11], 5.5\% in South Africa [12]. Diabetes mellitus has been reported to be more prevalent in urban area than in rural area. We can speculate that the difference of prevalence observed with these authors would partly be explained by the fact that some of these studies included rural and urban populations and some other only urban populations. The variable results reported in different studies can also be related to environmental and genetic factors which are known to influence the prevalence of diabetes and associated factors [13]. The influence of environmental and genetic factors in our study is demonstrated by the difference of prevalence between the different districts of the department. Prevalence of diabetes was very high in some districts of the department (15.3\%, 15.2\%, and 13.1\% respectively in the districts of Nikki, Sinendé and Tchaourou) and low in some others $(0.6 \%$ and $2.2 \%$ respectively in Pèrèrè and Bembèrkèdistricts) when general prevalence was $2.6 \%$ in Benin [5].

Regarding the tribes represented in the study, the highest prevalence (10.6\%) was evidenced in the Bariba ethnic group suggesting intervention of genetic and/or environmental factors in this tribe. High prevalence of diabetes had been reported in other African tribe like the Fulani tribe in Guinea [10] and the Haya tribe in Tanzania [14]. Intervention of the genetic factors in the pathogenesis of type 2 diabetes is well known [15]. Age over 40 years is known as risk factor for diabetes. Concordant with result of several studies [9] [13] [17], the prevalence of diabetes mellitus increased with age in our study. Concordant with some data reporting no difference with gender [8] [16]-[18], there was no significant difference between men and women in the prevalence of diabetes in our studies. In some other studies prevalence of diabetes was reported to be higher in men than in women [11] [12] [19]. On the other hand, Bradshaw in South Africa, Jean-Baptiste ED and al in Haiti, Esteghamati A and al in Iran reported a higher prevalence of diabetes in women than in men [13] [20] [21]. As reported by many other studies [22], other factors associated with diabetes mellitus in Benin are obesity and hypertension.

It is reported that a high proportion of diabetic subjects remain often undiagnosed [23]. The same figure was observed in the present survey. Only $12.8 \%$ of the diabetic subjects detected were known diabetic before. So, $87.2 \%$ of diabetic subjects were undiagnosed. This delay in diagnosis can explain the high rate of late complications observed in sub-Saharan African countries [24].

\section{Conclusion}

The present study shows a rapid progression of diabetes particularly in the Borgou department in Benin. An 
important proportion of these diabetic subjects remained undetected before the survey and thus untreated indicating the need for more active screening in certain areas and tribes. The prevalence rate varies between different areas and between different tribes of the department reflecting the effect of environmental and genetic factors. Classical risk factors were found associated with diabetes mellitus in Benin. Despite its limitations, this study provides baseline data for adequate planning of active interventions to prevent diabetes mellitus and its complications particularly in Borgou department where the disease is growing rapidly. For efficient prevention, further epidemiologic study is needed to identify specific risk factors.

\section{Acknowledgements}

Acknowledgements to the ministry of health of Benin which provided fond for the realization of this survey.

\section{References}

[1] King, H. and Rewers, M. (1992) Au nom du groupe spécial OMS sur la notification du diabète. Le diabète de l'adulte: désormais un problème dans le tiers monde. Bulletin de l'Organisation Mondial de la Santé, 70, 11-16.

[2] Mash, R.J., De Vrie, E. and Abdul, I. (2006) Diabetes in Africa: The New. Report on the $19^{\text {th }}$ World Diabetes Congress, Cape Town.

[3] King, H. and Rewers, M. (1993) Global Estimates for Prevalence of Diabetes Mellitus and Impaired Glucose Tolerance. WHO Ad Hoc Diabetes Reporting Group. Diabetes Care, 16, 157-177. http://dx.doi.org/10.2337/diacare.16.1.157

[4] Wild, S., Roglic, G., Green, A., Sicree, R. and King, H. (2004) Global Prevalence of Diabetes: Estimates for the Year 2000 and Projection for 2030. Diabetes Care, 27, 1047-1053. http://dx.doi.org/10.2337/diacare.27.5.1047

[5] Gning, S.B., Thiam, M., Fall, F., Ba-Fall, K., Mbaye, P.S. and Fourcade, L. (2007) Le diabète sucré en Afrique subsaharienne: Aspect épidémiologique, difficulté de prise en charge. Médecine Tropicale, 67, 607-611.

[6] Djrolo, F., Amoussou-Guenou, K.D., Zannou, D.M., Houinato, D., Ahouandogbo, F. and Houngbé, F. (2003) Prévalence du diabète sucré au Bénin. Louvain Médical, 122, S256-S260.

[7] Organisation Mondiale de la santé (2006) L’approche STEPwise de l’OMS pour la surveillance des facteurs de risque des maladies chroniques: Manuel de surveillance STEP de l'OMS, Genève.

[8] World Health Organization (1999) Definition, Diagnosis and Classification of Diabetes Mellitus and its Complications. Reports of a WHO Consultation. Part 1: Diagnosis and Classification of Diabetes Mellitus. WHO/NCS/99. 2.

[9] Balde, N.-M., Diallo, I., Baldé, M.-D., Barry, I.-S., Kaba, L., Diallo, M.-M., Kaké, A., Camara, A., Bah, D., Bah, D., Barry, M.-M., Sangaré-Bah, M. and Maugendre, D. (2007) Diabetes and Impaired Fasting Glucose in Rural and Urban Population in Futa Djallon (Guinea): Prevalence and Associated Risk Factors. Diabetes and Metabolism, 33, 114-120. http://dx.doi.org/10.1016/j.diabet.2006.10.001

[10] Gharbi, M., Akrout, M. and Zouari, B. (2002) Diabète non insulino-dépendant: prévalence et facteurs de risque en Tunisie. Revue d'Epidémiologie et de Santé Publique, 50, 349-355.

[11] Zahoui, S., Biémont, C. and Meguenni, K. (2007) Approche épidémiologique du diabète urbain et rural dans la région de Tlemcem (Ouest Algérien). Cahier Santé, 17, 15-21.

[12] Bradshaw, D., Norman, R., Pieterse, D. and Levitt, N.M., the South African Comparative Risk Assessment Collaborative Group (2007) Estimating the burden of disease attributable to diabetes in South Africa in 2000. South African Medical Journal, 97, 700-706.

[13] Arhén, B. and Corrigan, C.B. (1984) Prevalence of Diabetes Mellitus in North-Western Tanzania. Diabetologia, 26, 333-336.

[14] Simon, D. (2008) Définition, dépistage et épidémiologie du diabète de type 2. Médecine des Maladies Métaboliques, 2, S5-S9.

[15] Melidonis, A.M., Tournis, S.M., Kompoti, M.K., Lentzas, I.L., Roussou, V.R., Iraclianou, S.L., Michail, I.M. and Mariolis, A.M. (2006) Increase Prevalence of Diabetes Mellitus in a Rural Greek Population. Rural Remote Health, 6, 534.

[16] Nyenwe, A.E., Odia, J.O., Ihekwaba, A.E., Ojule, A. and Babatunde, S. (2003) Type 2 Diabetes in Adult Nigerians: A Study of Its Prevalence and Risk Factors in Port Harcourt, Nigeria. Diabetes Research and Clinical Practice, 62, 177185. http://dx.doi.org/10.1016/j.diabres.2003.07.002

[17] Bouguerra, R., Alberti, H., Salem, L.B., Rayana, C.B., Atti, J.E., Gaigi, S., et al. (2007) The Global Diabetes Pandemic: The Tunisian Experience. European Journal of Clinical Nutrition, 61, 160-165. http://dx.doi.org/10.1038/sj.ejcn.1602478 
[18] Latifa, B.H. (2007) Facteurs de risque cardiovasculaire dans la communauté urbaine de Tlemcen. Cahier Santé, 17, 153-158.

[19] Ozturk, Y., Aykut, M., Kelestimur, F., Gunay, O., Cetinkaya, F., Ceyhan, O. and Egri, M. (2000) Prevalence of Diabetes Mellitus and Affected Factors in the District of Kayseri Health Group Area. Turkish Journal of Medical Sciences, 30, 181-185.

[20] Jean-Baptiste, E.D., Larco, P., Charles-Larco, N., Vilgrain, C., Simon, D. and Charles, R. (2007) Glucose Intolerance and Other Cardiovasculaire Risk in Haiti. Prevalence of Diabetes and Hypertension in Haiti. BMC Public Health, 13, 326.

[21] Esteghamati, A., Gouya, M.M., Abbasi, M., Delavari, A., Alikhani, S. and Alaedini, F. (2008) National Survey of Risk Factors for Non-Communicable Disease of Iran. Diabetes Care, 31, 96-98.

[22] Ozdemir, L., Topçu, S., Nadir, I., Nur, N., Arslan, S. and Sümer, H. (2005) The Prevalence of Diabetes and Impaired Glucose Tolerance in Sivas, Central Anatolia, Turkey. Diabetes Care, 28, 795-798.

[23] Hadaegh, F., Bozorgmanesh, M.R., Ghasemi, A., Harati, H., Saadat, N. and Azizi, F. (2008) High Prevalence of Undiagnosed Diabetes and Abnormal Glucose Tolerance in the Iranian Urban Population: Tehran Lipid and Glucose Study. BMC Public Health, 8, 176-178. http://dx.doi.org/10.1186/1471-2458-8-176

[24] Sobngwi, E., Ndour-Mbaye, M., Boateng, K.A., Ramaiya, K.L., Njenga, E.W., Diop, S.N., et al. (2012) Type 2 Diabetes Control and Complications in Specialized Diabetes Care Centres of Six Sub-Saharan African Countries: The Diabcare Africa Study. Diabetes Research and Clinical Practice, 95, 30-36. 